From the Association of Family Medicine Residency Directors

Ann Fam Med 2008;6:278. DOI: 10.1370/afm.852.

\section{CORE CHARACTER TRAITS FOR FAMILY MEDICINE}

Family medicine residency programs spend a lot of time and energy formulating their rank order lists for the National Match. Faculty, staff, and residents spend many hours carefully scrutinizing dean's letters, transcripts, USMLE scores, letters of recommendation, and interview data. Each ERAS file has lots of data, but ironically, in this information age, there is precious little overt information about the applicant's character. It is left to each program to assess character based on brief interview experiences and the ERAS file. Yet, character is likely the core quality without which a resident may never master family medicine. As one Board member put it, "Character is the trump card. It doesn't matter what your USMLE scores are if you lack the character to be a family physician."

What are the character traits that make a good family physician? The AFMRD Board came up with the following:

1."Excellent interpersonal skills, compassionate, good work ethic, enthusiasm to learn, maturity, honesty, and a sense of humor."

2. "Character traits for a good FP: trustworthy, loyal, helpful, friendly, courteous, kind, obedient, cheerful, thrifty, brave, clean, reverent; actually that's what I memorized to be a good Boy Scout, but most of it applies to family medicine as well."

3. "There are 2 bottom-line principles of character that relate to work ethic: commitment to patients and commitment to colleagues. Representing the 'view from the trenches,' nothing is more infuriating to residents than colleagues who don't carry their weight. Whatever we can do to filter out weak/questionable commitment during the screening process is time well spent."

4. "Character is what you do when the lights are off and no one is looking."

The AFMRD Board created a resource tool that shares the Board's wisdom and experience in finding answers to these important questions:

1. How do you judge character from ERAS and your computer?

2. How do you assess character during an interview?

3. What can you discern about character from the applicant's behavior during the interview experience?
Answers to these questions and other useful ways to assess character may be found in this resource that is available at http://www.afmrd.org/cms/files///Resource_ library/AFMRD_resources/Core\%20Character\%20Trai ts\%20Final\%20Version\%202-29-08.pdf.

Not infrequently it is character traits or personality disorders that contribute to residents who are dismissed from programs, a very painful process for both parties. Although it is quite possible for certain personality and character traits to remain latent during medical school, they almost certainly become overt during the stress and demanding workload of residency. Is it time to use some of the well-validated psychological tools to help students match their character and personality with the specialty for which those traits are a good fit? There are clearly some personality and character traits that are not a good fit for family medicine.

In closing, here are 51 -liners on character from James Hunter's monograph on servant leadership':

- "Personality deals with style while character deals with substance."

- "Character is what we are beneath our personality."

- "Our character is our level of commitment to doing the right thing."

- "You can judge people's character by how they treat people who can do nothing for them."

- "Character is knowing the good, doing the good, and loving the good."

The AFMRD Board

Mark Robinson, $M D_{i}$ Paul Callaway, $M D_{i}$

Elissa Palmer, $M D_{i}$ Stan Kozakowski, $M D_{i}$ Sam Jones, $M D_{i}$ Sandra Carr, $M D_{i}$ Peter Carek, $M D_{i}$ Steve Cobb, $M D_{\text {i }}$ Joe Gravel, $M D_{i}$ Shirish Balachandra, MD

\section{Reference}

1. Hunter JC. The World's Most Powerful Leadership Principle: How to Become a Servant Leader. New York, NY: Crown Business; 2004.

\section{SAFP}

Ann Fam Med 2008;6:278-280. DOI: 10.1370/afm.850.

\section{MATCH RESULTS SHOW RESURGENCE IN FAMILY MEDICINE INTEREST}

Preliminary information from the 2008 National Resident Matching Program, or NRMP, indicates that 1,172 US medical school graduates-65 more than in 2007-chose family medicine for their careers, and 2,404 of 2,654 family medicine residency positions were taken, for a fill rate of nearly $91 \%$. 